\title{
O PASSE: A APROPRIAÇÃo ORIGINÁRIA DA METAFíSICA EM HEIDEGGER
}

\author{
[ THE TRANSITION: THE ORIGINAL APPROPRIATION OF METAPHYSICS IN HEIDEGGER ]
}

Resumo: Neste texto tratamos das meditações de Heidegger acerca da superação do primeiro princípio do pensamento como metafísica, tendo como principal questão a juntura (Fügung) do passe (das Zuspiel) no pensar fenomenológico do outro princípio. O que está em debate é o modo como a filosofia heideggeriana se apropria originariamente da metafísica a ponto de trazer à luz a confusão ontológica na qual ela esteve fixa durante séculos. Nesse sentido, o outro princípio assume a tarefa de indicar os limites do pensamento ocidental, situando-o na região do ente. Embora a ontologia da tradição tenha se cristalizado em meio ao ente, esquecendo-se do ser, ela é o que inspira Heidegger ao esforço de demonstrar de que forma o homem e a própria metafísica são fundados pela verdade originária (Seyn).

Palavras-chave: Heidegger; Passe; Metafísica; Ser; Princípio
ABSTRACT: In this text we deal with Heidegger's meditations on the overcoming of the first principle of thought as metaphysics, having as its main question the juncture (Fügung) of the transition (das Zuspiel) in the phenomenological thinking of the other principle. What is at issue is how Heidegger's philosophy originally appropriates metaphysics in order to bring to light the ontological confusion in which it has been fixed for centuries. In this sense, the other principle assumes the task of indicating the limits of Western thought by locating it in the region of the entity. Although the ontology of tradition has crystallized in the midst of the entity, forgetting the being, it is what inspires Heidegger to the effort to demonstrate how man and metaphysics itself are founded by the original truth (Seyn).
KEYWORDS:
Heidegger; Metaphysics; Being; Principle

\section{COLOCANDO A QUeSTÃo}

A discussão a qual nos propomos parte da juntura do passe (das Zuspiel) A presente na obra Contribuições à Filosofia (Do acontecimento apropriador). O texto original Beiträge zur Philosophie (Vom Ereignis) (1936-38) marca o amadurecimento do pensamento de Heidegger acerca da essência da verdade do ser (Wahrheit des Seyns) como fundamento abissal (Ab-grund). Desde então, nos escritos seguintes do filósofo, a saber, Serenidade (1944-45), A pobreza (1945), Sobre o humanismo (1946), entre outros textos iniciados e desenvolvidos até o seu falecimento em 1976, ecoam a verdade do ser como uma ocultação-clareante que se anuncia e se pronuncia como o nada do ente.

* Programa de Pós-graduação em filosofia na Univerisdade de Brasília - UnB. m@ilto: rodrigocasbr@hotmail.com 
Como se pode notar, grafamos Seyn com a letra "y" e dispensamos a vogal "i". Assim o fazemos, uma vez que, nas Contribuições à Filosofia, Heidegger evidencia o termo não mais com a moderna escrita alemã Sein. O intuito do pensador é fazer compreender que o ser do qual se fala é totalmente outro (ganz andere) ao que foi milenarmente questionado pela tradição ontológica. Nesse sentido, na viragem (Kehre) do pensar heideggeriano, ser se dá como a verdade abissal irrepresentável (Seyn).

As Contribuições à Filosofia, diferentemente da tradição metafísica, que esteve na dimensão da entidade do ente, a partir da ressonância ${ }^{1}$ (der Anklang) do ser, abre espaço, pela primeira vez na história do Ocidente, ao ecoar da verdade do ser (Seyn). Mas é com a junção (Fügung) do passe (das Zuspiel) que a história ruma para a preparação de uma ponte de transição do primeiro princípio ao outro princípio do pensar. Trata-se de uma conexão de jogo, um jogo de confrontação (Auseinandersetzung) entre os diferentes princípios, que proporciona espaço para o silêncio. No entanto, o suporte aqui não são novos sistemas filosóficos, mas uma transformação radical do pensamento. Ainda assim, faz-se necessário a direção e a decidida meditação histórica a respeito dos pensadores e de suas filosofias da história do primeiro princípio, gerando uma postura questionadora sobre eles. Essa meditação histórica, enquanto passagem dos princípios em si fundantes faz emergir, transitoriamente, a ponte para o outro princípio. Isso não se dá pela racionalidade lógica-científica do saber já dado pela filosofia, mas exige o salto, meditação esta que se encontra ainda incompreendida por ser abismal, distinta de tudo o que a história metafísica presenciou e questionou.

Mas, a partir das meditações de Heidegger nas Contribuições à Filosofia, de que princípios falamos? E que pólemos há entre eles? O primeiro princípio (erster Anfang) é o que rege a história da filosofia desde os gregos antigos até o pensamento contemporâneo. Tal princípio é metafísico, esquecedor do ser, uma vez que, durante milênios, identificou o ser com o ente, eliminando, assim, a diferença ontológica que há entre ambos. $\mathrm{O}$ outro princípio, que começa a se revelar no Ocidente a partir da ressonância do ser, atenta os ouvidos para a entoação originária, que passa a se anunciar como uma essência vazia, como um fundamento nulo. A nulidade do ser não indica uma ausência negativa ou um vazio sem significado, pelo contrário, ela é a vereda das possibilidades. O ser é nulo porque não pode ser representado pela vontade da subjetividade. O jogo de confrontação aqui se dá porque o outro princípio, em um passe de volta ao modo de vigência do ser no cerne da metafísica, busca meditar sobre a essência da verdade como retração fundante, permitindo à filosofia compreender de que modo esteve historicamente na zona do esquecimento do ser.

Discutir sobre o passe como a apropriação originária da metafisica é uma tentativa de compreender de que modo a ontologia tradicional (pensamento do primeiro princípio) pode ser superada e como se dá a transição ao outro princípio do pensamento (meditação fenomenológica), que suporta o ressoar do ser (Seyn) em sua dimensão abissal. Nessa passagem e nesse suportar, o ente humano passa a reconhecer o seu real fundamento.

\section{O PASSE PARA A SUPERAÇÃO DA METAFÍSICA}

O passe (das Zuspiel) indica um jogo de confrontação entre o outro princípio, que busca demonstrar, fenomenologicamente, de que forma o primeiro princípio, filosofia como metafísica, esqueceu a essência da verdade originária $(S e y n)$ e, nesse esquecimento, como o ente foi abandonado pelo ser. O outro princípio assume a 
responsabilidade de recolocar a metafísica em sua condição originária, demonstrando o limite de suas possibilidades e a sua finitude perante o singelo mistério do ser.

Para a metafísica, segundo Heidegger, o pensar se encontra presente junto ao ente, mas, ao mesmo tempo, o suplanta, pois busca o fundamento ôntico mais assente. Nessa busca, tanto mais resolutamente a filosofia se distancia da verdade do ser. Se continuamos no caminho do primeiro princípio, permanecemos inertes no domínio das representações. Mas aqui eis o grande pólemos nessa confrontação do passe (Zuspiel): se recusarmos a metafísica ao ente, não poderíamos ingressar na prisão do nada, já que o ente não seria mais o essencial? Haverá algum suporte fundamental que norteie o seraí (Da-sein) nesse caminho do outro princípio ou ele está plenamente só? Heidegger responde (2015, p. 167): “O ser-aí é a fundação da verdade do seer ${ }^{2}$. Quanto mais não ente o homem é, quanto menos ele se depara previamente com o ente como o qual ele é, se cristalizando aí, tanto mais próximo ele chega do seer. (Nenhum budismo! O

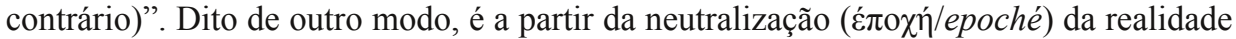
ôntica, isto é, quanto menos o homem se petrificar como um ente dado, mais (em sua facticidade como ser-aí) estará próximo do aberto do fundamento que dele se apropria. Não se trata de nenhum ascetismo no qual o homem despreza o seu corpo e o mundo terreno, mas indica a abertura à simplicidade do solo originário.

A não aceitação da simplicidade do ser é o que mais encobre essa verdade. Cada vez mais raro é a possibilidade de que o seu aceno se dê. É preciso, pela primeira vez na história do Ocidente, que o seu poder fundante seja reconhecido como a originariedade do existir. O que promove o rumar para o outro princípio do pensamento é a apropriação originária do primeiro princípio. Trata-se de um diálogo questionador (fragende Zwiesprache) com a tradição filosófica que não pode ser desprezada nessa passagem para uma outra história. O passe acontece na transição da questão diretriz (Leitfrage) (“o que é o ente?"), pergunta esta das ontologias tradicionais (entidade do ente, ser) à questão fundamental (Grundfrage) ("como vige o seer?").

O passe aqui explicitado por Heidegger é tratado como a verdadeira superação da metafísica (Überwindung der Metaphysik), onde ela se apresenta, de forma inédita na história, acessível em sua essência. A questão "o que é a metafísica?” instaurada na dimensão do passe ao outro princípio questiona a sua essência, sendo já uma conquista para o passe. Nesse labor indagativo, o que passa a ser visível como definição da metafísica já não é ela mesma, mas a sua superação. "Não se trata simplesmente de uma renovação, modernização da metafísica ou inovação a partir da reorganização e reconcepção de algo atual, mas de adquirir outra referência para com a história" (RAMOS, 2015, p. 286). A questão aqui levantada não almeja revisitar os conceitos sobre o pensamento ontológico, os posicionamentos de seus principais pensadores e poli-los, reinterpretando-os da melhor forma. O fato é que a metafísica é filosofia e que ela, essencialmente, identifica-se com a pergunta pela entidade do ente e não pela verdade do ser. Isto posto, a metafísica chega ao fim, porque o outro princípio, a partir do desvelamento do ser, já se apresenta, embora nebuloso e ainda não bem compreendido.

Heidegger salienta que, se a metafísica durante a história é um fato do ser-aí (Da-sein), esse fato não pode ser visto como uma criação antropológica da metafísica. A verdade do ser se funda no ser-aí e não este realiza aquela. Na passagem proposta por Heidegger (2015, p. 169), “agora o seer mesmo passou a se mostrar como originariamente dominante e um posicionamento da excedência do ente, o que significa, porém, sair do ente e, em verdade, como ente presente à vista e como objeto, se tornou impossível". Isso se dá porque a era do domínio do ente no primeiro princípio do pensamento está sendo iluminada pelo desvelamento do ser, que arroga para si o fundo 
de todo ente. Fica claro, pela primeira vez, o direcionamento à entidade do ente

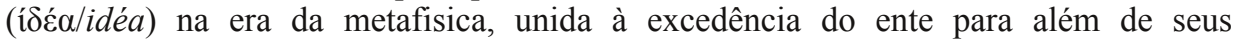
domínios, pois até o transcendente pode ser qualificado pela ontologia.

Os diversos e distintos posicionamentos acerca da essência da metafísica a definiram como uma fundação do próprio homem, negando a ela diferentes caminhos e possibilidades, já que estava a serviço da correção e do que suplanta as realidades singulares. No entanto, eis que surge, com Auguste Comte, a antimetafísica do positivismo, apresentando-se, igualmente, como uma nova metafísica, haja vista que tudo foi direcionado à entidade do ente - observação, experiência e manipulação de dados. Pelas conclusões comteanas, a metafísica foi tida como uma criança que sempre acreditou, imaturamente, no mundo transcendente das ideias, distante do palpável e do físico. Perguntamos: o que seria mais significativo: uma proteção expressa da antimetafísica positivista diante da metafísica tradicional? De forma alguma. Como diz Heidegger, no pensar transitório (Zuspiel) não está em jogo uma hostilidade à metafísica, mas a sua superação a partir do seu próprio fundamento que se instaura no primeiro princípio.

As Contribuições à Filosofia prenunciam que a metafísica chegou ao seu esgotamento. Mas qual é o real motivo desse acontecimento? Não por causa de seus vários questionamentos dirigidos à entidade do ente, "mas porque, de acordo com a queda do primeiro início, o seer, no fundo buscado, nunca teve como ser questionado com essa questão e, por fim, decaiu em meio ao impasse dessa impotência, na 'renovação' da 'ontologia"” (HEIDEGGER, 2015, p. 170). Ora, a metafísica “cai” porque o horizonte de seu primeiro princípio não a permitiu ingressar na dimensão do fundo do ser. A sua impotência para pensar o fundamento originário fez apenas os seus questionamentos renovarem, múltiplas vezes, as ontologias de Platão a Nietzsche, nunca chegando à zona do ser mesmo. Por ter jamais ousado indagar sobre a verdade elementar, a metafísica permaneceu no seu fio condutor representado pela questão diretriz (Leitfrage) "o que é a entidade do ente?".

Para Heidegger, o pensamento transitório não pode ser tentado a deixar o fím da metafísica para trás, mas, pelo contrário, deve trazê-lo para o jogo da verdade do ser. Pode-se dizer que o anúncio acerca desse fim não pode nos fazer pensar, de forma errônea, que a filosofia não teria mais nada a levar em consideração na metafísica. "Ao contrário: a metafísica, em sua impossibilidade essencial, precisa entrar agora, pela primeira vez, em uma conexão de jogo com a filosofia e a filosofia mesma, ser assim jogada para além de si, em direção ao seu outro início" (HEIDEGGER, 2015, p. 170) para acontecer a sua superação.

Superar salienta, indica Carneiro Leão, o trazer para trás e sob si mesmo, mas também indica o prospectar, o ir além. O trazer sob si mesmo, a fim de que aquilo que se almeja superar seja transformado por meio dessa superação. $\mathrm{O}$ ir além compreende a postura do pensar que almeja a transição em salto para o outro princípio. Aqui, a superação é pensada na dimensão histórico-ontológica enquanto a história do ser e nunca como um artefato (Gemächte) ou como um feito ôntico. Mas como se dá a superação aqui discutida? Heidegger busca evidenciar o histórico esquecimento do ser, isto é, o descuido da metafísica com a clareira-ocultante, ausência de zelo esta que permite a "primazia" da maquinação ${ }^{3}$. Desse modo, surgem duas significações acerca da questão da destruição da metafísica. A primeira se volta para a tarefa da construção de um novo plano conceitual, que deve rejeitar determinados conceitos da ontologia tradicional. A segunda, indica-nos a instância em que a metafísica é inserida em um plano histórico que tem o caráter ontológico, já que advém e sobrevém da destinação própria do esquecimento do ser. Como diz Heidegger (2000, p. 22) no texto Nietzsche: 
metafisica e niilismo (obra que reúne textos de 1938-1939 e de 1946-1948): "O abandono do ser é, porém, do ser". É o ser que se retrai ao ente. No entanto, o ente também faz parte desse abandono, haja vista que não abre espaço para o silêncio, para o não-necessário e para a carência de ser.

Superação da metafísica (Überwindung der Metaphysik) aponta para o enroscarse nela, o aprofundamento em seu interior, a ida ao seu fundo velado. A Überwindung, em sua essência, é Verwindung, transição que busca recuperação de uma moléstia, doença, ferimento. Überwindung indica o suportar a dor do ferimento, o consolar-se de um ferimento, esquecer uma dor (verschmerzen), uma ofensa. Por isso, o termo Verwindung indica Einwickeln: envolver-se (involvere). Superação, a partir desse modo essencial de ver, compreende o envolvimento profundo com a metafísica, o enroscar-se, o introduzir-se nela para o embate corpo a corpo com o que há de ser suplantado. Sobre tal questão, salienta Carneiro Leão no itinerário do pensamento de Heidegger em Introdução à metafísica (1935):

A superação da metafísica é, no fundo, uma recuperação originária do
esquecimento do Ser. Isso significa: a superação procura enuclear a
essencialização da metafísica e traçar, desse modo, os limites de suas
possibilidades [...] Pois o esquecimento do Ser é a própria dimensão, que,
escondendo-se a si mesma, protege a verdade da metafísica, possibilitando-lhe a
investigação do ente enquanto ente. Entendida assim epocalmente, a superação
não depõe a metafísica, mas a repõe em sua constante verdade, recompondo-lhe a
essencialização originária (CARNEIRO LEÃO, 1987, p. 19).

A exposição de Carneiro Leão é importante para entendermos o involvere com a metafísica a partir do dobrar-se e do desdobrar-se sobre o originário esquecimento do ser, desde o início da filosofia ocidental até os dias de hoje, a fim de esclarecer os limites de suas posições ontológicas. O intrigante é que o esquecimento do ser não é um mero esquecimento metafísico do fundamento originário. O esquecimento do ser esconde a si mesmo e se torna o protetor e conservador da verdade metafísica. Assim, o pensamento ocidental continua na investigação do ente enquanto ente, isto é, do ser do ente, da entidade do ente (essência do real). A história da metafísica, sem julgá-la como rebaixamento ou falha da história em continuar no percurso das modulações do ente, é uma reposição das suas posições em busca de sua verdade originária. Isso não significa uma progressão crítica de Heidegger a um domínio posterior, a um além transcendente, mas sim uma regressão, um retorno ao sítio interior e exterior da ontologia tradicional. A superação aqui proposta visa falar a linguagem vigente, servindo-se de suas posições e reposições. Trata-se de uma necessidade intrínseca que se aprofunda e navega nos títulos e na gramática da filosofia que vigora em cada época (ser e ente, superação e retorno, fundamento, essência, condição de possibilidade, imanência e transcendência, sensível e metassensível, corpóreo e incorpóreo, sensação e razão). Segundo Carneiro Leão, o modo de superação é

pro-jetivo enquanto, procurando superar a metafísica, pro-specta pensar a Verdade do Ser na configuração epocal do esquecimento. É re-gressivo, enquanto volta sobre esse ponto de partida para dilucidar a dimensão originária e a proveniência de seu vigor na vicissitude da Verdade do Ser (CARNEIRO LEÃO, 1987, p. 19).

Trata-se de uma ambiguidade acerca do sentido do ser e da concepção de superação. Nos trilhos desse duplo aceno, o projeto se instaura pelo re-gresso e, por isso, o retorno à Verdade do Ser como a instância originária da qual provém o esquecimento do Ser. É essa a única forma de se fazer a experiência da metafísica a partir do próprio modo epocal de essencialização da verdade fundamental. Assim, a 
ambiguidade que aqui impera se detém a mover-se, a todo momento, no plano do fundamento da metafísica. Contudo, a superação da metafísica, no sentido de prospecção, indica o ir além de seus conceitos e fundamentos.

A superação da metafísica não representa a sua mera inversão ou re-aplicação de conceitos já apresentados pela tradição. Como explica Heidegger (2000, p. 23): "é válido não [...] sucumbir ao perigo de que a superação se mantenha no interior da circunscrição e sob o modo de pensamento do que tem de ser superado - a metafísica -, apenas completando-o, aplicando e "re'-aplicando a si mesmo". Esse labor "destrutivo" não promoveria o ingresso no fundo oculto da tradição, mas propiciaria uma metafísica da metafísica.

Superação, essencialmente, aponta para libertação. Heidegger diz:

A superação não afasta meramente nem é tampouco somente um resgate de algo precedente. Ao contrário, ela é libertação de uma essência primevamente impassível de

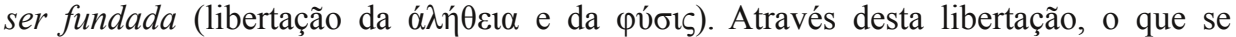
mostra aparentemente apenas como passado é alçado até o cerne de sua essência (descobrimento do encobrir-se enquanto tal) e torna-se essência perfeita. Esta essência não se deixa além disto suprassumir no futuro, mas recoloca-se, ao invés disto em si mesma enquanto principial (HEIDEGGER, 2000, p. 25).

$\mathrm{O}$ decisivo é que a superação da metafísica está situada na abertura de um fosso entre a entidade do ente e a verdade do ser. A superação pertence à história do ser, que nos tempos coevos, estrutura-se para a liberação do que funda toda historicidade e o sendo das entidades: o clareamento de que a essência do fundamento é o próprio encobrir-se no desvelamento. A essência apropriadora, isto é, aquela que se dá, essenciando-se nos entes, é o princípio fundante que funda a história e libera o ser-aí (Da-sein) para si mesmo. É justamente essa questão que o passse para o outro princípio aborda a seguir.

\section{A HISTÓRIA DO PRIMEIRO PRINCíPIO E O PASSE PARA O OUTRO PRINCÍPIO}

A história da metafísica, de acordo com Heidegger (2015, p. 171, grifos do autor), compreende que: "1. a entidade é presentidade; 2 o ser é um encobrir-se; 3 . o ente tem o primado; 4. a entidade é o suplemento e, por isso, o 'a priori". Esses são os pressupostos da metafísica que instauram a primazia do ente, que o faz esquecer a diferença ontológica. Se a verdade do ser não se tornar a questão necessária no campo de jogo temporal da passagem (Zuspiel), não teremos em vista que a história da metafísica é resultado de um acontecimento apropriador principiante, acontecimento este que é a própria vigência do ser nos entes.

A história da metafísica é a história do primeiro princípio. O que a explica aqui não são as tentativas de elucidar os seus posicionamentos, mas apenas a história da metafísica mesma. Ela não é uma doutrina filosófica, uma ciência ou uma disciplina. A filosofia é metafísica: o pensamento que pensa o ente no todo, a entidade do ente, o ser na perspectiva do ente. Ela pensa a partir do interesse do fundamento, isto é, a partir do que os gregos chamaram de ápx́́/arché, causa originária, ou como Kant demonstrou em sua epistemologia: o a priori como condição de possibilidade. Contudo, a história do primeiro princípio, história da filosofia como metafísica, não representa nenhuma diminuição ou contenção de si, mas é a exigência mesma de algo fundamental e originário. Além disso, não podemos cair na falsa compreensão de que as metafísicas que se deram durante a história são simples jogos deterministas ligados ao transcendente. "Ao contrário, a metafísica precisa ser levada a sério agora, que excede 
essencialmente toda assunção e toda herança contínua de peças doutrinárias, assim como toda renovação de pontos de vista e toda mistura e equilíbrio de muitos tais pontos de vista" (HEIDEGGER, 2015, p. 172).

A história da metafísica como história do primeiro princípio só vem à vista a partir do instante em que suas questões diretrizes a respeito da investigação sobre a entidade do ente são consideradas, buscando os seus desdobramentos. A questão diretriz aqui citada é a questão acerca do ente enquanto tal, que promove uma determinada abertura do ente, de tal forma que o homem experiencia a determinação de sua essência como homo animal rationale. Essa estabilidade do homem na dimensão racional atesta o fato de que pertence à vigência do ser a recusa, o retraimento ao ente. Essa recusa é própria do abandono do ser.

Esse saber [...] pensa o niilismo ainda mais originariamente em meio ao abandono do ser, a superação propriamente dita do niilismo, e a história do primeiro início é arrancada, assim, completamente da aparência de em vão e de mera errância; agora, pela primeira vez, a grande iluminação se abate sobre toda a obra pensante até aqui (HEIDEGGER, 2015, p. 172).

Heidegger elucida a essenciação do ser como aquela que abandona o ente a partir de sua recusa, compreendendo o pensamento originário, já que isso representa o próprio niilismo na medida em que a vigência do aberto instala o homem no abismal do $N a d a$, porque ser é um fundamento nulo e não se dá à determinação da entidade. Dessa forma, clareia-se a ideia de que a história do primeiro princípio não permaneceu em equívocos do ente, já que tudo que ocorreu nesse período se deu a partir da constrição do fundamento que se funda no ser-aí (Da-sein).

O passe ao outro princípio da história só pode ser possível se compreendermos que por mais que o ente tenha grande poderio maquinal nos diversos campos da realidade (político, econômico, cultural, social), o futuro do Ocidente está em pensar a questão acerca do ente tendo em vista a questão acerca da verdade primordial. "O seer, contudo, até aqui sob a figura da entidade, o que havia de mais universal e corrente, torna-se, enquanto acontecimento apropriador, o que há de mais único e estranho" (HEIDEGGER, 2015, p. 173). Assim, com o pressentimento de outra inicial abertura da simplicidade fundamental (Seyn), a configuração do ente como a realidade mais presente e geral passa a ser considerada como aquilo que é apropriado pelo único e estranho fundamento originário. É um princípio estranho porque é totalmente diferente de todas as figurações ônticas representadas pelo pensamento ocidental até os tempos coevos.

O passe ao outro princípio propicia uma cesura, um corte com a história da metafísica e uma grande abertura que se distancia da maquinação (técnica) do primado do ente e de suas visões de mundo. Esse caminhar de um princípio ao outro "cinde a emergência do ser e a fundação de sua verdade na existência de toda ocorrência e apreensão do ente" (HEIDEGGER, pp. 173-174). Nesse sentido, a decisão (Entscheidung) transitiva gera a cisão, uma fissuração (Klüftung) explícita na diferença ontológica entre a renúncia e o deixar-ser (ser), o renunciado e o deixado-ser (ente). Aqui não há qualquer equilíbrio e entendimento inicial entre ambos, já que a passagem ao outro princípio é um acontecimento em tormenta e em nebulosidade, porque sair do mundo das representações seguras do ente à verdade do ser é o passe para o abismal. $\mathrm{O}$ fato é que essa transição ainda é um prenúncio e não uma realidade. A prova disso é que o desvelamento velado do ser ainda continua diminuto graças à artificialidade, à aparência do homem e de seus feitos maquinais, que reduz o real ao factível da vida e de suas vivências. 
O ser deixa-se desvelar em sua essenciação originária e fundante. Trata-se do mistério principial como acontecimento apropriador (Ereignis). Referimo-nos ao Ereignis a partir do Ur-äugnis, isto é, da mirada originária, que nos apresenta o processo que se abre e que deixa vir cada coisa à visibilidade. E o esteio que faz o aparecer e permite o sair do encoberto e, assim, há o revelar-se. Heidegger traz o vocábulo äugen para deixar latente o sentido fundamental de Ur-äugnis: tornar visível, fazer-se ver, deixar-ser. Esse sentido essencial do termo possibilita pensarmos o ser como aquilo que se mostra e se desvela em ostentação e em espetáculo. Por isso, Ereignis não aparece tão só como um acometimento radical apropriador. De outro modo, há justamente des-apropriação nessa ocorrência, já que o mistério é o puro deixar-ser de si mesmo, é o seu acontecer ostentoso e espetacular em seu desvelamento velado, é o livre-que-libera.

O que testemunha que a história ocidental, no passe em direção ao outro princípio, ruma ao fundo abissal é a seguinte passagem das Contribuições à Filosofia: "A transição para o outro início está decidida e, contudo, não sabemos para onde estamos indo, quando a verdade do seer se tornará o verdadeiro e a partir de onde a história enquanto história do seer tomará a sua via mais íngreme e mais curta" (HEIDEGGER, 2015, p. 174, grifos do autor). Por ser uma travessia a um fundamento nulo, para o não da recusa, esse espantoso e sereno caminhar para o outro princípio tende a compelir o homem a não deixar a sua zona confortável das vivências ônticas, na qual a plena certeza impera e onde tudo é possível graças ao cálculo do ente. Conceber a negação é tão raro e difícil em uma era onde vivemos sob o reino do sim, do impossível sendo perfeitamente possível. O que se dá é a rejeição e a degradação da negação. Deste modo, é extirpado o pensar na possibilidade de que o não pode ter mais profundidade do que o assentimento superficial do sim.

No entanto, quem diz o não ou sim não é o ser-aí (Da-sein) apropriado pelo ser $($ Seyn), podendo acatar a retirada deste último? Com a assunção da negação, o não indica um salto livre do ser-aí em meio à recusa do fundamento. "O salto livre mesmo assume, pela primeira vez, o ressaltar o salto, e, assim, o não ultrapassa aqui o sim" (HEIDEGGER, 2015, p. 175, grifos meus). O não aqui é a despedida do outro princípio em relação ao primeiro princípio. Não se trata de negação no sentido usual entitativo, no qual se nega uma vivência para se assumir outra mais significativa. Pelo contrário, referimo-nos à recusa do aberto, reconhecendo a unidade do ser como exigência fundamental para o passe ao outro princípio do pensar.

Aqui há o salto que implica em uma confiabilidade (Verlässigkeit) no abismo como recusa. Salto porque o passe não é regulado por nenhuma condição lógicaracional do ente, uma vez que no outro princípio o ser-aí passa a percorrer o caminho irrepresentável do ser. No entanto, o abismo para o qual o salto ruma não é negativo. Ele se dirige ao sein-lassen, ao deixar-ser que promove abertura de mundo, ao livreque-libera. O salto indica: "Na medida em que se nos concentra tudo no espiritual, propicia-se [ereignet sich] o ser pobre. Sobre este se afina a essência do humano. A pobreza é a tônica da essência ainda encoberta dos povos ocidentais e do seu destino" (HEIDEGGER, 2004, p. 233). O salto, como podemos notar, é o caminho para a pobreza, isto é, para o não-necessário, para o abrir-se do Ereignis. A pobreza é a possibilidade da alegria por parte do ente por este nunca ser suficiente rico, já que não se completa em si mesmo. Daí o salto para o abismo (Seyn), esse desconhecido que hoje se prenuncia, que pode propiciar a mais pura serenidade (Gelassenheit), pronta a superar o que é relativo à necessidade maquinal.

Para Heidegger, o primeiro princípio não deixa o ser se dar como recusa, mas, pelo contrário, busca representá-lo sem se questionar acerca da verdade essencial. A 
essência do ente, enquanto tal, permanece velada, preponderando a sua própria verdade, porque ele mesmo dizima o Nada, negando a negação do não (recusa vigente do ser). Já o outro princípio do pensar experimenta o solo da essenciação e pergunta a respeito da verdade insondável, em busca de deixar despontar as possibilidades que daí podem advir. No primeiro princípio, o pensamento se estabelece sob o fundo da questão diretriz da metafísica, esse sendo o insondado do princípio, o próprio cânone do pensar ontológico e o fio condutor da filosofia ocidental.

Chega-se o momento em que a filosofia busca, para si, o asseguramento de si mesma. A ratio dos medievos em união com a fides caminham para a segurança da certeza no critério de medida dos modernos com Descartes, quando esse pensador substitui a veritas est adaequatio rei et intellectus (a verdade é a conformidade do pensamento à coisa) em vista à essência da certitudo (o ente que é com toda certeza). Sobre essa questão, Heidegger, na obra Que é isto - a filosofia? (1955), declara:

Descartes, em suas meditações, pergunta: qual é aquele ente que no sentido do ens certum é o verdadeiro ente? Para Descartes, entretanto, se transformou a essência na certitudo [...] Para ele, a dúvida se torna aquela dis-posição em que vibra o acordo com o ens certum, o ente que é com toda certeza. A certitudo torna-se aquela fixação do ens qua ens, que resulta da indubitabilidade do cogito (ergo) sum para o ego do homem [...] De acordo com esta certitudo, recebe o dizer de Descartes a determinação de um clare et distincte percipere. A dis-posição afetiva da dúvida é o positivo acordo com a certeza (HEIDEGGER, 1973, p. 220).

Para Descartes, o princípio da indubitabilidade dos entes é a egoidade, a entidade do ente como o ens certum. O ente humano é tão certo que até mesmo quando ele é assaltado pela dúvida é esta que o instala como verdadeiro, dado que quem duvida pensa e, pensando, existe necessariamente como certitudo. A subjetividade - que agora é "objetiva" porque é certitudo - está contraposta ao objeto como certeza calculante, podendo ter percepções claras e distintas (clare et distincte percipere). Modifica-se a determinação da entidade do ente, transformando-a em objetividade. Pensar é certeza e objetualidade é entidade. "A verdade se transforma na determinação do ente que se tornou algo objetivo (verdade como correção do juízo, 'objetividade', 'realidade efetiva' - ser do ente" (HEIDEGGER, 2015, p. 181).

$\mathrm{Na}$ Modernidade estamos diante de objetivações e representações para que o homem técnico-calculante esteja certo e seguro do ente. Acerca dessa compreensão, Heidegger (1998a, p. 110), na conferência O tempo da imagem do mundo (1938), nos diz: "Só se chega à ciência como investigação se, e apenas se, a verdade se transformou em certeza do representar. É na metafísica de Descartes que o ente é, pela primeira vez, determinado como objetividade do representar e a verdade como certeza do representar". Descartes é um filósofo do primeiro princípio e o seu filosofar já representa a vontade de poder do ente na dimensão do cálculo. Nesse sentido, diz Heidegger (1998a, p. 123): “Com Descartes, começa a consumação da metafísica ocidental" e, com Nietzsche, o seu ápice. Todavia, o filósofo alemão, com a transvaloração de todos os valores, promovendo a inversão do platonismo, permanece no cerne da metafísica, já que "A fuga para o interior do 'devir' ('vida') é metafisicamente apenas uma saída” (HEIDEGGER, 2015, p. 178). Essa saída é uma porta de ingresso no pensar da tradição, porque Nietzsche, em defesa da transmutação de todos os valores e do amor fati, designa o poder à factibilidade do fazer ôntico. Em seu pensamento, ainda permanece fixa e constante a oposição entre as dimensões física e metafísica. Dessa forma, "Toda a metafisica moderna, incluindo Nietzsche, mantémse na interpretação do ente e da verdade traçada por Descartes" (HEIDEGGER, 1998a, p. 110), isto é, o sujeito como fundamento de todos os valores, a verdade do ente 
instaurando o domínio da subjetividade. Como explicita Heidegger em A palavra de Nietzsche "Deus morreu (1943):

Nietzsche permanece, apesar de todas as inversões e transmutações da metafisica, no caminho ininterrupto das suas tradições, quando chama simplesmente ser ou ente ou verdade ao que é fixado na vontade de poder para a sua manutenção. De acordo com isso, a verdade é uma condição posta na essência da vontade de poder, a condição da manutenção do poder. A verdade é, enquanto esta condição, um valor (HEIDEGGER, 1998b, p. 276).

A metafísica, outrossim em Nietzsche, inclina-se a perguntar pelo ser do ente, enquanto a superação dessa constância indica perguntar, antes de tudo, pela verdade do ser, essa essência que não se tornou uma questão digna para a metafísica. Em Ser e tempo, em sua ontologia fundamental, Heidegger propôs essa transição para pensar a metafísica de forma mais originária a fim de superá-la. Tratou-se não mais de pensar ente e entidade, mas ser. Nas Contribuições à Filosofia, a questão é a própria essenciação do ser, primeira e originária. Mais radical do que transvalorar todos os valores dados pela metafísica ou mais profundo do que Sartre que, igualmente permaneceu imerso na ontologia tradicional na sua inversão do platonismo com a tese de que "a existência precede a essência", Heidegger está no caminho do colocar em questão a ratio da tradição. O próprio filósofo elucida: "o que importa também não é apenas a inversão da metafísica até aqui, mas a essenciação mais originária da verdade do ser enquanto acontecimento apropriador" (HEIDEGGER, 2015, p. 179).

Mas perguntamos: por que Sartre, um pensador crítico severo da ontologia tradicional, cai na metafísica que busca superar? No texto Sobre o humanismo (1946), Heidegger responde:

Sartre expressa o princípio fundamental do Existencialismo do seguinte modo: a existência precede a essência. Ele toma aqui existentia e essentia no sentido da metafísica, que desde Platão diz: a essentia antecede a existentia. Sartre inverte os termos dessa frase. Ora, a inversão de uma frase metafísica continua sendo uma frase metafísica. Assim como sua frase, continua ele com a metafísica, no esquecimento da Verdade do Ser (HEIDEGGER, 1967, pp. 47-48).

Inversões são meras trocas de posições que não atingem realmente a questão principal e essencial: o modo de essenciação do ser e o dar-se de sua verdade. Assim, Heidegger expõe (2015, pp. 180-181, grifo do autor): “Agora, porém, faz-se necessária a grande inversão que está além de toda 'transvaloração de todos os valores', daquela inversão, na qual o ente não é fundado a partir do homem, mas o ser do homem a partir do seer". O elo entre ser e ente se torna distinto, não doutrinário e nem dogmático, mas vigente e fundante, onde a questão diretriz não mais se impõe, não existindo o primado e nem a normatividade ôntica.

Vê-se que o passe para a interioridade do outro princípio implica em um aprofundamento no primeiro princípio por meio da repetição (Wiederholung). Entendase o termo no sentido de retorno, revolvimento, retomada, resgate do pensamento, todavia, não no caráter de uma transposição a algo passado para repeti-lo, torná-lo real e efetivo hoje. Repetir (wiederholen) é perguntar e pensar de novo acerca da questão do ser. O seu escopo é acolher o não dito no que foi pronunciado durante a história e aterse ao silenciado nas manifestações epocais. É pensar o mistério nadificador que se "escorre" durante as "fundações" dos homens. Em relação a isso, Deleuze, em Diferença e repetição, escreve:

Repetir é comportar-se, mas em relação a algo único ou singular, algo que não tem semelhante ou equivalente. Como conduta externa, esta repetição talvez seja 
o eco de uma vibração mais secreta, de uma repetição interior e mais profunda no singular que a anima. A festa não tem outro paradoxo aparente: repetir um "irrecomeçável". Não acrescentar uma segunda e uma terceira vez à primeira, mas elevar a primeira vez à "enésima" potência (DELEUZE, 2006, p. 11).

Quando se repete, resgata-se uma unidade conceitual singular que se deu durante um momento histórico. Repetir é fazer vibrar o que já ecoou anteriormente, o que Deleuze chama de "irrecomeçável" por ser singular em seus próprios termos. A principal questão da repetição, para o pensador francês, não indica meros acréscimos ao conceito revisitado, mais profundo do que isso, compreende elevar o elemento conceitual a partir de um confrontamento histórico, e que, deste pólemos, seja considerado o que durante séculos ou milênios esteve oculto. É o que a fenomenologia heideggeriana busca: enxergar o não dito nos ditos da tradição ontológica, pensar o oculto esquecimento do ser nas várias teorizações sobre o fundamento. Assim, Heidegger instaura o diálogo (Gespräch) com os filósofos do primeiro princípio a fim de preparar a transição e o salto ao outro princípio.

O diálogo, por meio da repetição, que Heidegger instaura com a tradição filosófica não é pacificador por se tratar de confrontamento, discussão, levando em conta o termo em sua origem latina discutere, como tensão dialógica que permite trazer à originalidade do que está em causa (Sache). $\mathrm{O}$ seu questionar de novo ("wieder"fragen) acerca do fundamento indagado pelos pensadores do primeiro princípio intenta perguntar sobre a essenciação do ser de modo ainda mais profundo do que o fizeram os predecessores. Com a repetição (Wiederholung), inicia-se a destruição (Destruktion) na metafísica, isto é, a elucidação de seus limites e o questionamento de seus fundamentos. Destarte,

Investigar: o que há com o Ser? - não significa nada menos do que re-petir o princípio de nossa existência espiritual-Histórica, a fim de transformá-lo em um outro princípio [...] Um princípio, porém, não se re-pete, voltando para ele como algo de outros tempos e hoje já conhecido, que meramente se deve imitar. Um princípio se repete, deixando-se que ele principie de novo, de modo originário, com tudo o que um verdadeiro princípio traz consigo de estranho, obscuro e incerto (HEIDEGGER, 1987, p. 65, grifos do autor).

A repetição é a assunção do que, em outros momentos estruturais da história do Ocidente ficou velado, perdido ou esquecido. Assume-se a estranheza e a obscuridade do que esteve em causa no primeiro princípio e que, agora, volta a ser uma questão fundamental. Esse revolvimento do pensar está em caráter de distanciamento necessário, pois é preciso ter experiência com a essência daquilo que se iniciou, isto é, com a pergunta diretriz e com a primazia desse questionar. Deve-se ter o cuidado para não se alienar às modulações do primeiro princípio. "O retorno ao primeiro início é precisamente um distanciamento dele, a vinculação daquela posição distante, que é necessária, a fim de experimentar aquilo que se iniciou naquele início e como aquele início" (HEIDEGGER, 2015, p. 181). Trata-se de uma posição de distanciamento, porque se permanecermos próximos demais do primeiro princípio, pode ocorrer de ficarmos fatidicamente com a verdade essencial encoberta e estagnada no campo de visão da questão ontológica da tradição acerca da entidade. Mas, ao mesmo tempo, devemos nos aprofundar nessa questão tão formulada e respondida pela metafísica. Aqui se dá a repetição: esse pedir de novo o acesso à questão, um aprofundamento em sua essência no sentido de superação da metafísica que discutimos anteriormente: superação como o enroscar-se nela, o profundo navegar em seu interior para o combate corpo a corpo com a questão do esquecimento do ser, a fim de compreendermos os limites de suas possibilidades. 
É no revolvimento ao primeiro princípio que é possível conceber o fato de que a verdade como desvelamento na ó $\lambda \eta ́ \theta \varepsilon ı /$ alétheia permaneceu inquestionada, e de que esse evento definiu o pensar ocidental como o pensar da metafísica. É só a partir desse conhecimento que surge a emergência de preparar o outro princípio e experimentar o que daí ocorre: a condição finita na qual o homem se encontra a partir da plena claridade que demonstra o abandono do ser durante a história. Para a alteração da história ocidental, as decisões que virão não podem se pautar naquilo que Heidegger chama de contramovimentos (cultura e visão de mundo), mas o sítio da decisão precisa estar em meio à abertura da unicidade da verdade do ser em oposição, também, à primazia do ente. Até mesmo os contramovimentos à metafísica pendem a ela como as inversões do platonismo em Nietzsche, em Sartre e no cientificismo positivista. Para não se lançar no mesmo solo entitativo da ontologia tradicional, o outro princípio está fora do plano do contra e do a favor. "O outro início não é a direção contrária em relação ao primeiro início, mas se encontra como outro fora do contra e da comparabilidade imediata" (HEIDEGGER, 2015, p. 183). Essa passagem demonstra como a superação da metafísica não é antimetafísica. O escopo não é opor-se a ela sob a forma de uma inversão - o que é estabelecido pelo positivismo, pela transvaloração de todos os valores em Nietzsche e pela primazia da existência sobre a essência em Sartre. Contrário ao pressuposto da inversão, o outro princípio é a recuperação do primeiro princípio, no sentido de sua recondução ao seu chão: o acontecimento apropriador (Ereignis) como mirada originária (Eräugnis). Aqui, a questão não é ser defensor ou não da metafísica, mas se trata de ser o outro dela, o outro que recupera o lugar da identidade da tradição sob a instância da verdade do ser.

Estar fora do contra ou do a favor significa estar fora do tomar partido, não ter como ponto de transformação da história do Ocidente a cultura e as visões de mundo. Os contramovimentos não se demonstram suficientes para uma alteração essencial da história, haja vista que se respaldam na entidade do ente para criticar, transformar e vencer questões. Não foi o que fizeram Nietzsche, Sartre e o positivismo comteano nos seus contramovimentos em oposição ao platonismo? Heidegger apela para o ir além das forças, impulsos e instituições contrárias para o diverso do domínio do ente ser possível. Porém, o confronto entre um princípio e o outro não indica concorrência e desafeto com a metafísica. "O outro início auxilia a partir de uma nova originariedade o primeiro início para a verdade de sua história [...] que só se torna frutífera no diálogo histórico dos pensadores" (HEIDEGGER, 2015, p. 183). O outro princípio não se coloca a perder a metafísica. Pelo contrário, o labor aqui é essencial, pois, pela primeira vez, a metafísica é posta em sua verdade e, dessa forma, passa a ser transformada.

Não estamos falando de um outro princípio do pensamento na acepção de um novo começo. Trata-se de um outro princípio que se situa no Outro do Mesmo, isto é, na história do ser que de épocas em épocas se deixa e se faz ver. Cada época representa uma configuração histórica do esquecimento de ser. $\mathrm{O}$ outro princípio não anula a história do primeiro princípio (metafísica), mas nele se aprofunda e o repõe em sua verdade. No itinerário de Introdução à Metafísica de Heidegger, Emanuel Carneiro Leão completa (1987, p. 11): “[...] a metafísica grega não é algo que num tempo foi e agora já não é mais. Não se trata de um presente para sempre passado. É um pretérito ainda hoje presente no vigor e no império da ciência e da técnica". Entendida dessa forma, epocalmente, a superação não depõe contra a metafísica, mas é, no fundo, uma recuperação originária do esquecimento do ser. 
A fenomenologia de Heidegger, na fase de viragem (Kehre), vigora como o pensamento do passe (das Zuspiel): a meditação que solicita acesso à questão acerca da essência encoberta em âmbito metafísico. Trata-se de uma repetição (Wiederholung), que re-pede a possibilidade de ingresso ao fundo basilar dos caminhos do pensamento re-velados aos homens nestes dois séculos e meio de história ocidental. No entanto, a repetição fenomenológica de Heidegger em nada tem em comum com reprodução de conteúdo já dado. Repetir é um modo essencial de apropriação do que a história lega ao presente.

A história legada é a do primeiro princípio (metafísica) à posteridade, que permite o passe e o pensar àqueles que hoje estão dispostos a suportar e acolher este chamado no outro princípio (meditação fenomenológica sobre a verdade do ser como abismo). Tal passe não se dá na calmaria de tempos seguros. O outro princípio se choca como o primeiro princípio em um combate face a face, em um choque originário, tendo-se como busca legítima recuperar o nada do ser. Como se vê, as meditações do outro princípio em Heidegger não buscam aniquilar a metafísica, mas destruí-la. Destruição não significa devastar a questão-alvo a ponto de não a ter mais à vista. A existência do pensamento metafísico e a sua conservação são necessárias para que o aprofundamento em seu fundo esquecedor do ser se consume. Nesse sentido, Heidegger não é o filósofo que busca depor contra a metafísica. No passe, ele tenta repô-la em sua condição originária.

Compreende-se que a essência da juntura do passe nas Contribuições à Filosofia tem como papel principal anunciar o vazio no qual as modulações metafísicas caem em suas buscas pela correção e pela verdade absoluta (ser). A "queda" aqui se dá porque o ser, essencialmente irrepresentável por qualquer judicação, passa ao largo de quaisquer nomeações que sejam designadas a ele. Por isso que Heidegger, na obra Serenidade, medita sobre o ser como a vigência que não tem nome (namelos). Nas Contribuições à Filosofia, este sem-nome é dito como Seyn e demonstra que o ser do qual se "fala" é completamente outro do ser da história ontológica presente no ocidente.

O passe não evidencia apenas a essência da metafísica como o fundo que traça a história do primeiro princípio na zona do esquecimento do ser. Essa juntura faz ver que o ser-aí (Da-sein), este deslocado do mundo da técnica e do falatório desmedido, pode existir como o acolhedor do ser. Mas só há custódia da verdade originária se por ela o ser-aí for acolhido. É só a partir do toque fundamental no ser-aí que há acontecimento apropriador (Ereignis). Paradoxalmente, tal acontecimento desapropria-se do homem e se retira em velamento. A desapropriação (Ent-eignis) do ser lança o humano no mundo como um ente situado em sua condição fáctica de projeto finito.

Por fim, entendemos que o projeto do passe nas Contribuições à Filosofia anuncia que o homem sempre esteve e estará sem solo, porque a verdade do ser como fundamento abismal não está rente ao cálculo. Portanto, mesmo que a atual conjuntura de empreendimentos técnicos rumo à factibilidade emergente continue para elevar a vontade de poder do ente sobre o globo, a diferença ontológica será o marco essencial que deixará o homem sempre em condição de finitude. O reconhecimento dessa facticidade, de que o ser é originário e não se deixa dominar, é o que faz do ser-aí ( $D a$ sein) um ser rico. Todavia, a sua riqueza está em seu pudor, em sua serenidade e em seu silêncio para escutar as entoações que o tornam cada vez mais aberto ao nada.

\section{REFERÊNCIAS}

CARNEIRO LEÃO, Emmanuel. Itinerário do pensamento de Heidegger. In: HEIDEGGER, 
Martin. Introdução à metafísica. Rio de Janeiro: Tempo Brasileiro, 1987.

DELEUZE, Gilles. Repetição e diferença. In: Diferença e repetição. Rio de Janeiro: Graal, 2006.

HEIDEGGER, Martin. A superação da metafísica. In: Nietzsche: metafísica e niilismo. Rio de Janeiro: Relume Dumará, 2000.

HEIDEGGER, Martin. Introdução à metafísica. Rio de Janeiro: Tempo Brasileiro, 1987.

174 HEIDEGGER, Martin. O que é isto - a filosofia? In: Os Pensadores. São Paulo: Abril Cultural, 1973.

HEIDEGGER, Martin. O tempo da imagem do mundo. In: Caminhos de Floresta. Lisboa: Fundação Calouste Gulbenkian, 1998a.

HEIDEGGER, Martin. A palavra de Nietzsche "Deus morreu". In: Caminhos de Floresta: Lisboa: Fundação Calouste Gulbenkian, 1998b.

HEIDEGGER, Martin. A pobreza. In: Phainomenon: Journal of Phenomenological Philosophy, n. ${ }^{\circ}$ 24. Lisboa, 2014, pp. 227-234. Disponível em: <http://www.phainomenonjournal.pt/index.php/phainomenon/article/view/320/268>.

HEIDEGGER, Martin. Contribuições à filosofia (Do acontecimento apropriador). Rio de Janeiro: Via Verita, 2015.

HEIDEGGER, Martin. Sobre o humanismo. Rio de Janeiro: Tempo Brasileiro, 1967.

RAMOS, Daniel Rodrigues. O Ereignis em Heidegger. Teresópolis: Daimon, 2015.

\section{Notas}

1 Ressonância é a primeira juntura (Fügung) das Beiträge de Heidegger. Ela anuncia o ressoar do ser no ente como a essência que durante toda a história do pensamento ocidental estive retraída, todavia em modo de apropriação do homem de tempos em tempos. A ressonância do ser é o que traz o abalo essencial a ponto de ecoar o caráter nulo do fundamento. $\mathrm{O}$ ressoar do ser como o Nada fundante na ressonância é o que prepara a história do primeiro princípio como metafísica ao passe (das Zuspiel) para o outro princípio do pensar no Ocidente, onde o ser-aí (Da-sein) se torna um ser apropriado e fundado pelo mistério originário.

2 Seer é a grafia portuguesa usada por Marco Antônio Casanova em sua tradução da palavra Seyn advinda do texto Beiträge zur Philosophie. Neste artigo, optamos por continuar com a grafia ser, já que pelo contexto da nossa discussão e pelas informações contidas na introdução deste trabalho, o leitor está informado que estamos tratando da questão do ser em sua total diferença ontológica e abismal em relação ao ente.

3 Maquinação (Machenschaft) é o processo técnico no qual o homem mergulha para se situar no mundo. $\mathrm{O}$ ente maquinal é aquele que esquece do real fundamento que dele se apropria e se compreende como a própria verdade, fazendo da vontade do sujeito a primazia. 